\title{
IPTEKS BAGI MASYARAKAT DESA MLATIHARJO MENUJU PENGELOLAAN KOMODITAS DESA BERBASIS DIGITAL
}

\author{
Suprihadi $^{1}$ \\ Radius Tanone ${ }^{2}$ \\ Rudy Latuperissa ${ }^{3}$ \\ 1Program Studi Teknik Informatika Universitas Kristen Satya Wacana \\ 2Program Studi Teknik Informatika Universitas Kristen Satya Wacana ${ }^{2}$ \\ 3Program Studi Sistem Informasi Universitas Kristen Satya Wacana ${ }^{3}$ \\ e-mail :suprihadi@staff.uksw.edu,radius.tanone@staff.uksw.edu, \\ rudi.latuperissa@staff.uksw.edu
}

Diterima: 2 Juli 2018/ Disetujui : 18 Juli 2018

\begin{abstract}
Mlatiharjo is a village in Demak District, Central Java province, it has been well-known as an innovative village because of their various innovations especially in high quality (supreme) seed varieties of fruit and rice. In order to support the production and cultivation of those commodities, information management has been employed but still in simple ways and doesn't have any information system yet, therefore it often causes mistake in their production estimation. It will impact to their sales service of their commodities toward the buyer, particularly the customer. Another problem is Mlatiharjo's farmer group does not have any information exchange medium to interact with other business actors who comes from outside their area, whereas those outsider-business actors will buy their product with a higher price. Mlatiharjo's IbM Program aims to build an Information System which is able to manage the information of Mlatiharjo's commodities production, especially in farming production. The method employed for developing the system is Prototyping. Meanwhile, the transfer of technology employs mentoring process for the client of program through conducting focus group discussion, workshop dan training. This Commodity Information System is implemented into two kinds of computer application. Firstly, web application that is used for managing the data center and share it to the public who want to capture the information of the mlatiharjo's product. Secondly, android based mobile application utilized by the farmer who has become a member of cluster-farming group to input the location area mapping data and progress report of production data and also provide a discussion forum among member of the system. The Web Application is built using PHP and the database used MySQL. Mobile Application is implemented using Java Android. As a result, Tani Mahardika Cluster and KSU Citra Kinaraya - Mlatiharjo have a digital-based system to manage their Commodity in order to encourage and strengthen business-production institution through Commodity Information System.
\end{abstract}

Keywords : Information System, Farming Commodity, Mlatiharjo Village.

\begin{abstract}
ABSTRAK
Desa Mlatiharjo Kecamatan Gajah Kabupaten Demak Jawa Tengah, sebagai desa inovatif telah melakukan berbagai inovasi dalam bidang bibit buah unggulan dan padi varietas unggulan. Pengelolaan informasi oleh kelompok tani guna menunjang produksi dan budidaya komoditas unggulan desa tersebut, masih sangat sederhana dan belum memiliki sebuah sistem informasi, sehingga sering terjadi kesalahan estimasi perhitungan hasil produksi. Hal ini berdampak pada
\end{abstract}


pelayanan penjualan produk komoditas desa kepada pembeli khususnya pelanggan. Permasalahan lain adalah kelompok tani belum memiliki sarana media pertukaran informasi kepada pelaku usaha di luar wilayah desa, padahal harga jual komoditas memiliki harga lebih tinggi jika dibeli oleh pembeli dari luar daerah desa Mlatiharjo. Program IbM Desa Mlatiharjo ini bertujuan membangun sebuah sistem informasi yang mampu mengelola informasi usaha produksi komoditas desa Mlatiharjo, khususnya komoditi pertanian. Metode pengembangan sistem yang digunakan adalah metode prototyping, sedangkan transfer teknologi menggunakan metode pendampingan kepada mitra program berupa kegiatan focus group discussion, workshop, dan pelatihan. Sistem Informasi Komoditas Desa diimplementasikan kedalam 2 jenis aplikasi yaitu pertama, aplikasi web guna mengelola pusat data, dan bagi publik untuk mendapatkan informasi usaha produksi komoditas desa Mlatiharjo. Kedua, aplikasi mobile berbasis Android untuk petani anggota klaster pertanian untuk memasukkan data-data terkait pemetaan lokasi lahan, progres report info produksi, dan forum diskusi antar anggota sistem. Aplikasi web diimplementasikan menggunakan bahasa PHP dan basis data MySql. Aplikasi mobile diimplementasikan menggunakan Java Android. Dengan demikian, Klaster Tani Mahardika dan KSU Citra Kinaraya Desa Mlatiharjo dalam upaya peningkatan penguatan kelembagaan usaha produksi dan budidaya pertanian sebagai komoditas desa, dapat terwujud melalui Sistem Informasi Komoditas Desa Mlatiharjo sebagai aplikasi pengelolaan komoditas desa berbasis digital.

Kata Kunci : Sistem Informasi, Komoditas Pertanian, Desa Mlatiharjo.

\section{PENDAHULUAN}

Mlatiharjo, merupakan sebuah desa yang terletak di pesisir utara pulau jawa. Terletak di sebelah selatan timur dari kota Kabupaten Demak, berbatasan langsung dengan Kabupaten Kudus. Di lewati beberapa saluran irigasi besar, pertanian merupakan kegiatan sehari-hari warga desa yang menggantungkan pencukupan ekonomi dari lahan persawahan yang menghasilkan komoditas berupa padi, palawija, dan hortikultura atau buah-buahan. Selain yang dihasilkan dari lahan persawahan, komoditas lain yang dihasilkan masyarakat desa Mlatiharjo adalah dari usaha peternakan dan perikanan. Secara Administratif, desa Mlatiharjo merupakan wilayah Kecamatan Gajah Kabupaten Demak.

Walau sebagai salah satu desa pemasok stok pangan nasional, kehidupan masyarakat petani desa belum bisa sejahtera dan termarjinalkan. Mata pencaharian sebagai petani belum bisa memberikan harapan yang begitu berarti. Hal ini disebabkan karena informasi terkait komoditas yang diusahakan belum dapat tersebar secara luas di tingkat regional, apalagi secara nasional, sehingga harga komoditas tersebut hanya memiliki daya saing yang rendah.

Berbekal kenyataan tersebut, segala aspekpun digerakkan oleh pemerintah desa dalam upaya dapat memberikan harapan adanya peningkatan pendapatan kepada petani dan masyarakat desa. Untuk lebih mengenal desa Mlatiharjo, dapat dilihat pada gambar 1. mengenai data monografi desa.

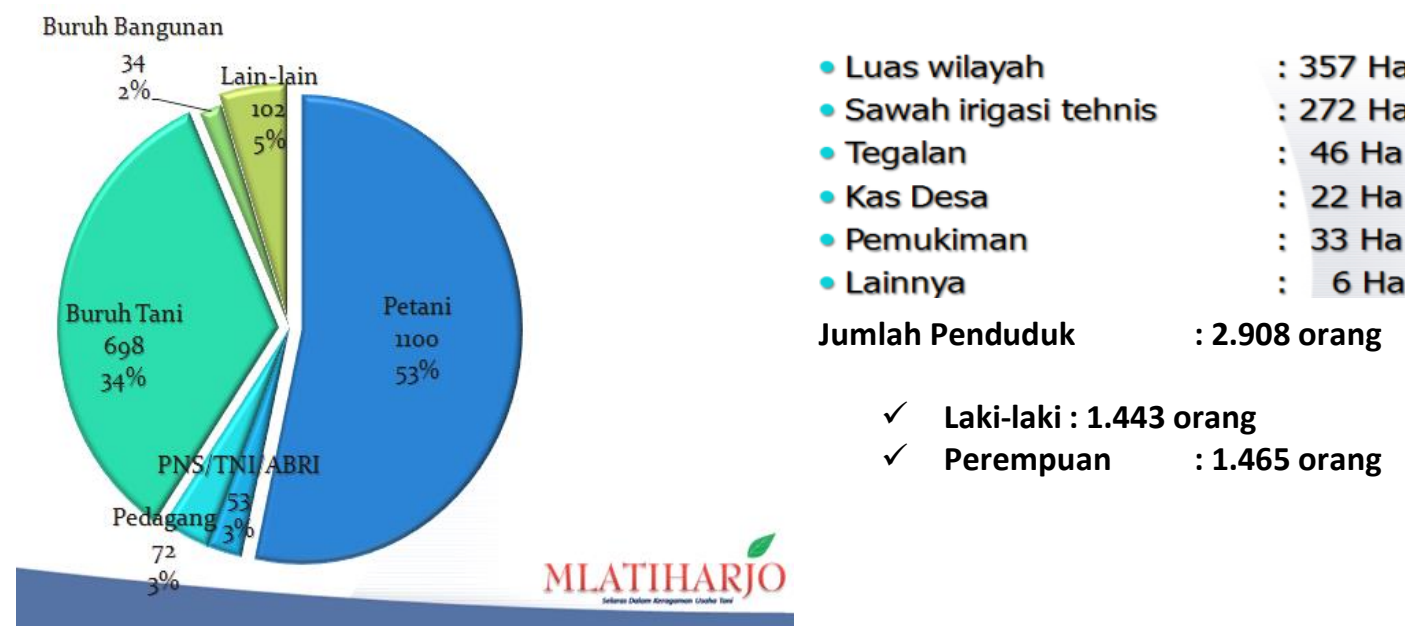

Gambar 1. Monografi Desa Mlatiharjo[1] 
Berbekal kenyataan di lapangan yang sedemikian rupa dan dengan dukungan dari banyak pihak, elemen masyarakat, kelembagaan desa dan SDM terdidik, maka kegiatan dalam rangka peningkatan kesejahteraan masyarakat desa mulai dikembangkan dan dirumuskan kedalam kerangka inovasi desa Mlatiharjo.

Desa Mlatiharjo, Kecamatan Gajah, Kabupaten Demak Jawa Tengah mendapat anugerah gelar sebagai Desa Inovatif versi Balitbang Jawa Tengah pada bulan Mei tahun 2011. Desa Inovatif adalah sebuah desa yang mampu memanfaatkan sumber daya desa dengan cara yang baru. Hal tersebut telah dibuktikan dengan adanya kegiatan-kegiatan inovasi dari masyarakat desa yang tergabung didalam sebuah Klaster Pertanian, yaitu melakukan pengelolaan budidaya pertanian, peternakan dan perikanan secara terpadu, berkesinambungan, dan berkualitas, sehingga menghasilkan komoditas yang diharapkan. Untuk dapat memperjelas hal tersebut, maka dapat dilihat pada tabel 1 yaitu daftar komoditas desa Mlatiharjo yang dikelola dan diproduksi melalui budidaya usaha anggota klaster pertanian Tani Mahardika, serta data harga penjualan dalam kurun waktu satu tahun terakhir.

Tabel 1. Data Produksi dan Harga Jual Komoditas Desa Mlatiharjo pada tahun 2014[2]

\begin{tabular}{|c|c|c|c|c|}
\hline \multirow[t]{2}{*}{ No. } & \multirow[t]{2}{*}{ Jenis Komoditas } & \multirow{2}{*}{$\begin{array}{c}\text { Rerata Qty } \\
\text { Produksi } \\
\text { Per Tahun } \\
\text { (dalam Ton) }\end{array}$} & \multicolumn{2}{|c|}{$\begin{array}{c}\text { Harga Jual Per Kg berdasarkan Daerah } \\
\text { Asal Pembeli } \\
\text { (Rupiah) }\end{array}$} \\
\hline & & & Lokal Kab. & Luar Kab. \\
\hline \multicolumn{5}{|c|}{ Tanaman Pangan } \\
\hline 1. & Padi & 3.840 & 4.600 & - \\
\hline 2. & Kacang Hijau & 240 & 10.000 & 16.000 \\
\hline \multicolumn{5}{|c|}{ Hortikultura } \\
\hline 1. & Kelengkeng & 1 & 18.000 & 35.000 \\
\hline 2. & Semangka & 360 & 2.400 & 2.500 \\
\hline 3. & Jambu Kristal & 1 & 6.000 & 12.000 \\
\hline 7. & Melon & 120 & 6.000 & 6.100 \\
\hline 8. & Cabe Keriting & 1,6 & 20.000 & 21.000 \\
\hline 9. & Cabe Rawit & 2,4 & 15.000 & 16.000 \\
\hline 10. & Bawang Merah & 80 & 19.000 & 20.000 \\
\hline 11. & Ketimun & 30 & 1.500 & 1.600 \\
\hline 12. & Tomat & 20 & 2.000 & 2.100 \\
\hline 13. & Sawi Hijau & 1,5 & 4.000 & 4.500 \\
\hline 14. & Terong & 3 & 2.000 & 2.100 \\
\hline \multicolumn{5}{|c|}{ Peternakan } \\
\hline \multirow[t]{3}{*}{1} & Telur Bebek & 20,4 & 36.000 & 38.400 \\
\hline & & $\begin{array}{l}\text { Rerata Qty } \\
\text { Produksi } \\
\text { Per Tahun }\end{array}$ & \multicolumn{2}{|c|}{$\begin{array}{c}\text { Harga Jual Per Ekor berdasarkan Daerah } \\
\text { Asal Pembeli } \\
\text { (Rupiah) }\end{array}$} \\
\hline & & (dalam Ekor) & Lokal Kab. & Luar Kab. \\
\hline 2. & Sapi Potong & 64 & $20 \mathrm{jt}$ & $25 \mathrm{jt}$ \\
\hline 3. & Kambing /Domba & 250 & $2,5 \mathrm{jt}$ & $3 \mathrm{jt}$ \\
\hline 4. & Bebek & 2100 & 25.000 & 30.000 \\
\hline 5. & Ayam Lokal & 5200 & 80.000 & 90.000 \\
\hline
\end{tabular}

Berdasarkan tabel 1 tersebut, maka terlihat bahwa komoditas desa Mlatiharjo memiliki nilai jual lebih jika terjadi pada transaksi jual beli dengan Pembeli dari luar daerah desa atau luar daerah kabupaten Demak, antara lain Kabupaten Kudus, Kabupaten dan Kota Semarang, Kota Yogyakarta, Kabupaten Indramayu dan DKI Jakarta. Selain usaha tersebut, untuk menjaga kesinambungan produksi komoditas desa, desa Mlatiharjo juga mengembangkan bibit buah unggul. Salah satu contoh bibit buah unggul hasil inovasi desa yaitu buah Klengkeng. Tanaman Klengkeng hasil inovasi desa tersebut mampu hidup di daerah dataran rendah, tetapi menghasilkan kualitas buah yang unggul yaitu 
ukuran lebih besar, manis dan selalu menghasilkan buah tanpa mengenal musim. Hasil inovasi desa Mlatiharjo pada bibit buah unggul dapat dilihat pada tabel 2 dibawah ini.

Tabel 2. Usaha Produksi dan Penjualan Bibit Tanaman Buah Unggulan Desa Mlatiharjo[2]

\begin{tabular}{|c|c|c|c|c|c|c|c|}
\hline \multirow[t]{2}{*}{ No. } & \multirow[t]{2}{*}{ Jenis Produk } & \multicolumn{3}{|c|}{$\begin{array}{c}\text { Qty Produksi per tahun } \\
\text { ( Batang) }\end{array}$} & \multicolumn{3}{|c|}{$\begin{array}{c}\text { Qty Penjualan per tahun } \\
\text { ( Batang) }\end{array}$} \\
\hline & & 2012 & 2013 & 2014 & 2012 & 2013 & 2014 \\
\hline 1 & Bibit klengkeng & 7.000 & 7.500 & 8.500 & 7.000 & 7.100 & 8.200 \\
\hline 2 & Bibit Belimbing & - & 3.500 & 3.500 & - & 1.500 & 2.000 \\
\hline 3 & Sawo Jumbo & 4.000 & 4.500 & 4.500 & 3.600 & 4.000 & 3.800 \\
\hline \multirow[t]{2}{*}{ No. } & \multirow{2}{*}{ Jenis Produk } & \multicolumn{3}{|c|}{$\begin{array}{c}\text { Qty Produksi per tahun } \\
\text { ( Batang) }\end{array}$} & \multicolumn{3}{|c|}{$\begin{array}{c}\text { Qty Penjualan per tahun } \\
\text { ( Batang) }\end{array}$} \\
\hline & & 2012 & 2013 & 2014 & 2012 & 2013 & 2014 \\
\hline 4 & Srikaya Jumbo & 2.000 & 2.000 & 2.000 & 2.500 & 3.000 & 2.800 \\
\hline 5 & Jambu Kristal & 7.500 & 8.000 & 8.000 & 7.200 & 7.500 & 7.500 \\
\hline 6 & Nangka Genjah & 9.000 & 10.000 & 12.000 & 8.500 & 9.600 & 11.300 \\
\hline
\end{tabular}

Berdasarkan profil klaster, data tabel 1 dan tabel 2, maka dapat diketahui bahwa masyarakat desa Mlatiharjo selain melakukan usaha produksi, masyarakat desa juga telah melakukan usaha penjualan terhadap komoditas hasil produksi pertanian, serta bibit padi spesifik dan benih buah unggulan. Oleh masyarakat desa, usaha kegiatan penjualan hasil inovasi tersebut dilakukan dan dikelola oleh badan usaha berupa Koperasi Serba Usaha (KSU) yang mereka didirikan pada tahun 2008 dan disahkan secara hukum pada tahun 2011 yang diberi nama KSU Citra Kinaraya. Badan usaha ini diharapkan dapat menjadi sarana penunjang utama masyarakat desa dalam rangka meningkatkan pertumbuhan ekonomi lokal yaitu peningkatan pendapatan berbasis rumah tangga, dimana hal ini merupakan program utama masyarakat desa Mlatiharjo.

\section{PERMASALAHAN}

Berdasarkan data yang tersaji, dapat diidentifikasikan adanya permasalahan atau kebutuhan solusi dari desa Mlatiharjo khususnya dalam rangka usaha peningkatan nilai jual komoditas dan hasil inovasi masyarakat desa, serta jaminan akan kepastian pasar atau pembeli komoditas desa pada saat masa panen, yang dapat diketahui atau ditentukan saat masyarakat masih musim tanam atau melakukan proses produksi. Secara umum desa Mlatiharjo memiliki keterbatasan didalam penguasaan penggunaan fasilitas teknologi informasi. Sementara itu, tuntutan setiap pelaku usaha (termasuk petani) atas penggunaan dan penguasaan teknologi untuk mampu menyajikan informasi secara cepat dan akurat sudah terasa semakin mendesak, mengingat tingkat persaingan di pasar lokal, regional maupun global. Selain melakukan usaha pemasaran, desa Mlatiharjo juga membutuhkan sebuah teknologi yang mampu mengelola komoditas desa beserta lahan wilayah budidaya sebagai asset masyarakat desa. Dengan demikian, pemerintah desa dapat melakukan perencanaan dan pembinaan secara tepat dalam pengembangan komoditas desa sebagai salah satu usaha peningkatan pendapatan masyarakat desa, khususnya petani dan pelaku usaha komoditi desa yang tergabung dalam Klaster Pertanian Tani Mahardika.

Data KSU Citra Kinaraya juga memberikan beberapa fakta bahwa pengelola sering mengalami kesalahan estimasi antara kemampuan penyediaan barang komoditas desa dengan tingginya tingkat permintaan pasar. Kondisi ini membutuhkan suatu solusi yang komprehensif dengan memanfaatkan teknologi informasi. Permasalahan lain, yaitu adanya kelemahan dalam sistem pembukuan / pencatatan atas luas dan posisi letak geografis wilayah lahan budidaya, jenis budidaya, estimasi waktu panen, dan estimasi hasil panen atau produksi, karena Klaster maupun KSU belum memanfaatkan aplikasi teknologi informasi secara optimal.

Untuk mampu merespon hal tersebut maka dibutuhkan dukungan pelatihan dan penguatan SDM bagi Klaster maupun KSU untuk mampu mengoperasikan aplikasi Teknologi Informasi dan 
Komunikasi serta penguasaan Internet. Kebutuhan media pelatihan bagi SDM Klaster Tani Mahardika untuk mampu menjawab tantangan persaingan pada pasar global, sementara kebutuhan pendampingan yang diharapkan mampu memberikan solusi bagi pengembangan dan penguatan manajemen usaha KSU Citra Kinaraya dan Klaster Tani Mahardika. Kebutuhan pelatihan atas teknologi tepat guna di bidang pemetaan wilayah geografis lahan guna mampu dalam pengembangan digitalisasi data, penggunaan aplikasi mobile, dan teknologi informasi dan komunikasi yang dibutuhkan untuk mampu mengelola komoditi masyarakat desa sebagai komoditas desa yang unik dan memiliki daya jual tinggi.

Tingginya tingkat persaingan pada era pasar bebas, menuntut kesiapan pelaku usaha yang ada untuk segera mempersiapkan diri guna menghadapi persaingan pada era perdagangan global. Untuk menghadapi situasi tersebut, maka dibutuhkan suatu sentuhan teknologi yang mampu mendorong pelaku usaha, khususnya masyarakat desa untuk siap bersaing. Persaingan yang terjadi menuntut peningkatan efisiensi kolektif dari kegiatan usaha dengan menerapkan teknologi informatika, upaya yang dilakukan adalah mendorong migrasi tradisi pengelolaan dan pemasaran komoditas secara manual dan bersifat lokal, menjadi pengelolaan dan pemasaran komoditas secara digital dan dapat diakses secara global, sehingga diharapkan akan mampu memberikan efisiensi kerja pemasaran yang tinggi, memberikan peluang waktu lebih lama bagi pemasaran, yaitu dapat dilakukan semenjak awal musim tanam budidaya komoditi, sehingga produk usaha terutama komoditas Desa Mlatiharjo yang ada mampu bersaing secara terbuka, dan memiliki nilai jual yang lebih tinggi.

Mengacu pada berbagai permasalahan tersebut diatas, maka permasalahan utama yang dihadapi oleh kedua kelompok mitra (KSU Citra Kinaraya dan Klaster Tani Mahardika) di desa Mlatiharjo adalah pertama, bagaimana mengelola komoditas masyarakat desa secara profesional, sehingga dapat menyajikan informasi antara lain profil petani atau pelaku usaha, waktu tanam, waktu panen, letak geografis lahan, estimasi hasil panen, dan riwayat pengelolaan dan transaksi penjualan, yang dapat diakses oleh pengelola maupun publik secara online? Kedua, bagaimana menerapkan teknologi informasi dan komunikasi dalam usaha pemasaran dan distribusi produk anggota Klaster sebagai komoditas desa, untuk dapat memperluas jangkauan pemasaran dan mampu menjalin komunikasi serta peningkatan layanan kepada pelanggan?

Dengan demikian, target luaran sebagai hasil program $\mathrm{I}_{\mathrm{b}} \mathrm{M}$ Desa Mlatiharjo Menuju Pengelolaan Komoditas Desa Berbasis Digital adalah pertama, program pendampingan dan pelatihan pengelolaan komoditas bagi klaster Tani Mahardika selaku pengelola sistem komoditas desa berbasis mobile Desa Mlatiharjo. Kedua, paten domain web aplikasi Komoditas Desa Mlatiharjo sebagai Pusat Data. Ketiga, SOP (Standard Operation Procedure) aplikasi pengelolaan komoditas desa. Keempat, aplikasi Komoditas Desa berbasis web dan mobile.

\section{LITERATURE REVIEW}

Aplikasi web Sistem Informasi Komoditas Desa Mlatiharjo diimplementasikan menggunakan framerowk CodeIgniter. Alasan kenapa menggunakan framework PHP yaitu CodeIgniter adalah pertama gratis, karena CodeIgniter dilisensikan di bawah Apache. Kedua, berjalan di PHP versi 4 dan 5. Ketiga, ringan dan cepat karena hanya berjalan dengan menggunakan beberapa pustaka saja. Dengan demikian hanya membutuhkan sumber daya (resource) yang sedikit sehingga ringan dan cepat dijalankan. Keempat, menggunakan MVC. CodeIgniter menggunakan lingkungan pengembangan dengan metode MVC (Model View Controller) yang membedakan antara logika dan tampilan, sehingga proyek bisa lebih mudah dipecah-pecah. Ada bagian yang khusus membuat tampilan dan bagian yang membuat kode programmnya. Kelima, dokumentasi. Salah satu hal yang bisa dijadikan barometer apakah sebuah aplikasi benar-benar dikembangkan atau tidak bisa dilihat dari dokumentasinya. Dalam hal ini CodeIgniter sangat luar biasa, terdapat dokumentasi yang sangat lengkap tentang semua hal yang ada dalam CodeIgniter. Keenam, pustaka yang lengkap, yaitu CodeIgniter dilengkapi dengan berbagai pustaka siap pakai untuk berbagai kebutuhan, misalnya saja koneksi database, email, session, keamanan, manipulasi gambar dan banyak lagi [3].

Sistem Informasi Komoditas Desa Mlatiharjo juga dilengkapi dengan aplikasi mobile yang berfungsi untuk pemberitahuan (notifikasi) informasi transaksi yang terjadi pada aplikasi kepada para actor sistem. Aplikasi mobile yang sering juga disebut dengan mobile computing adalah sebuah 
teknologi yang memungkinkan transmisi data melalui komputer, tanpa harus terhubung dengan suatu fixed physical link. Mobile computing meliputi antara lain Laptop dengan wireless LAN, mobile phone, wearable computer dan Personal Digital Assistant (PDA) dengan Bluetooth atau IRDA [4]. Keuntungan teknologi mobile adalah pertama, extreme personalization karena penyimpanan Ponsel diantara dompet dan kunci motor, dan dapat digunakan sebagai tempat menyimpan segala informasi pribadi; kedua, pengaksesan informasi setiap saat dan dimanapun, sehingga memungkinkan kita untuk bekerja, belanja atau bermain tanpa batasan waktu dan tempat (asal terhubung!); ketiga, mobilitas tinggi tanpa kerumitan kabel (W-LAN) dan instalasi jaringan yang cepat; keempat, compatible yang tinggi dengan teknologi lain; kelima, cocok untuk daerah yang belum ada infrastruktur; keenam, reduksi biaya yaitu dalam kasus pengembangan, pemindahan maupun perubahan konfigurasi LAN.

Metode notifikasi yang dipergunakan pada aplikasi mobile Komoditas Desa Mlatiharjo adalah Push Message. Push Message merupakan komunikasi jaringan dimana server akan mengirimkan pesan ke client jika ada perubahan data, sehingga client tidak perlu melakukan proses request data tiap periode untuk mengambil data notifikasi. Pada teknologi Push Message untuk device mobile sangat efektif karena berjalan pada background proses sehingga memungkinkan aplikasi menerima pesan. Push Messasge dapat diimplementasikan pada beberapa device mobile diantaranya Android, pada sistem operasi Android proses Push Message dapat memanfaatkan layanan Google Cloud Messaging (GCM) untuk mengirim pesan/notifikasi; Apple, pada sistem operasi iOS proses Push Message dapat memanfaatkan layanan Apple Push Notification Service (APNS) untuk mengirim pesan/notifikasi; Windows Phone, pada sistem operasi Windows Phone proses Push Message dapat memanfaatkan layanan Microsoft Push Notification Service (MPNS) untuk mengirim pesan/ notifikasi; Blackberry, pada sistem operasi Blackberry OS proses Push Message dapat memanfaatkan layanan Blackberry Push Service untuk mengirim pesan/ notifikasi [5].

Beberapa penelitian yang telah dilakukan terkait teknologi informasi bidang komoditas pertanian antara lain pada tahun 2008 dengan judul Aplikasi Sistem Informasi Geografis Untuk Analisis Kesesuaian Lahan Pertanian Di Propinsi Daerah Istimewa Yogyakarta [6]. Penelitian tersebut bertujuan mengembangkan model integrasi antar faktor fisik dan sosial ekonomi dalam menentukan prioritas arahan pengembangan di sektor pertanian, terutama untuk menentukan jenis komoditas yang paling sesuai pada suatu satuan lahan atau wilayah tertentu yang menjadi daerah basis pertanian. Hasil penelitian menunjukkan bahwa lahan di Provinsi DIY yang sangat sesuai untuk tanaman padi sebesar $25,4 \%$, sedangkan untuk tanaman kacang tanah lebih kecil lagi yaitu $16 \%$ dan untuk tanaman jagung hanya $2 \%$.

Penelitian di tahun 2012 yaitu Ketersediaan Sumber Informasi Teknologi Pertanian Di Beberapa Kabupaten Di Jawa [7], bertujuan untuk menganalisis ketersediaan sumber informasi teknologi pertanian dalam rangka memenuhi kebutuhan informasi petani. Hasil penelitian menunjukkan bahwa informasi teknologi pertanian yang tersedia masih terbatas pada informasi tentang varietas unggul, pemupukan, alat dan mesin pertanian, serta cara pembuatan dan pemberian pakan.

Pada tahun 2014 penelitian berjudul Sistem Informasi Geografis Komoditas Dan Luas Lahan Pertanian Berbasis Android Di Kabupaten Magelang, telah menghasilkan sebuah aplikasi mobile untuk memudahkan masyarakat melihat hasil pertanian dan luas lahan pada setiap kecamatan di Kabupaten Magelang [8].

Putra E. U., Yantu M. R. dan Sulaeman pada tahun 2015 telah melakukan penelitian dengan judul Pengembangan Sistem Informasi Agribisnis Desa Labuan Toposo Kecamatan Labuan Kabupaten Donggala [9]. Penelitian ini bertujuan mengembangkan sistem informasi agribisnis Desa Labuan Toposo secara khusus subsistem proses (usaha tani). Hasil penelitian tersebut adalah sebuah sistem informasi agribisnis yang berupa aplikasi pendataan kelompok beserta anggotanya serta data mengenai komoditi pertanian dan website yang dapat menampilkan informasi-informasi pertanian Desa Labuan Toposo.

Penelitian terkait pengembangan sistem informasi komoditas pertanian juga dilakukan pada tahun 2016 berjudul Sistem Informasi Geografis Pemetaan Lahan Pertanian Dan Komoditi Hasil Panen Kabupaten Kudus [10]. Hasil penelitian tersebut adalah sebuah aplikasi web untuk membantu Dinas Pertanian, Perikanan dan Kehutanan Kabupaten Kudus mendata hasil komoditi panen dan mempunyai data pemetaan suatu daerah atau wilayah, sehingga dapat cepat mengetahui hasil komoditi pada suatu kecamatan atau desa di wilayah Kabupaten Kudus. 
Kelima hasil penelitian yang telah dilakukan sangat berbeda dengan hasil program $\mathrm{I}_{\mathrm{b}} \mathrm{M}$ Desa Mlatiharjo Menuju Pengelolaan Komoditas Desa Berbasis Digital, yaitu pertama, program pendampingan dan pelatihan pengelolaan komoditas bagi klaster Tani Mahardika selaku pengelola sistem komoditas desa berbasis mobile Desa Mlatiharjo. Kedua, paten domain web aplikasi Komoditas Desa Mlatiharjo sebagai Pusat Data. Ketiga, SOP (Standard Operation Procedure) aplikasi pengelolaan komoditas desa. Keempat, aplikasi Komoditas Desa berbasis web dan mobile.

\section{HASIL DAN PEMBAHASAN}

Metodologi yang digunakan dalam penyelesaian permasalahan mitra adalah pertama, pengembangan pusat data dan aplikasi mobile komoditas desa. Kedua, pendampingan dalam pengelolaan komoditas desa. Untuk lebih jelasnya dapat dilihat pada gambar 2.

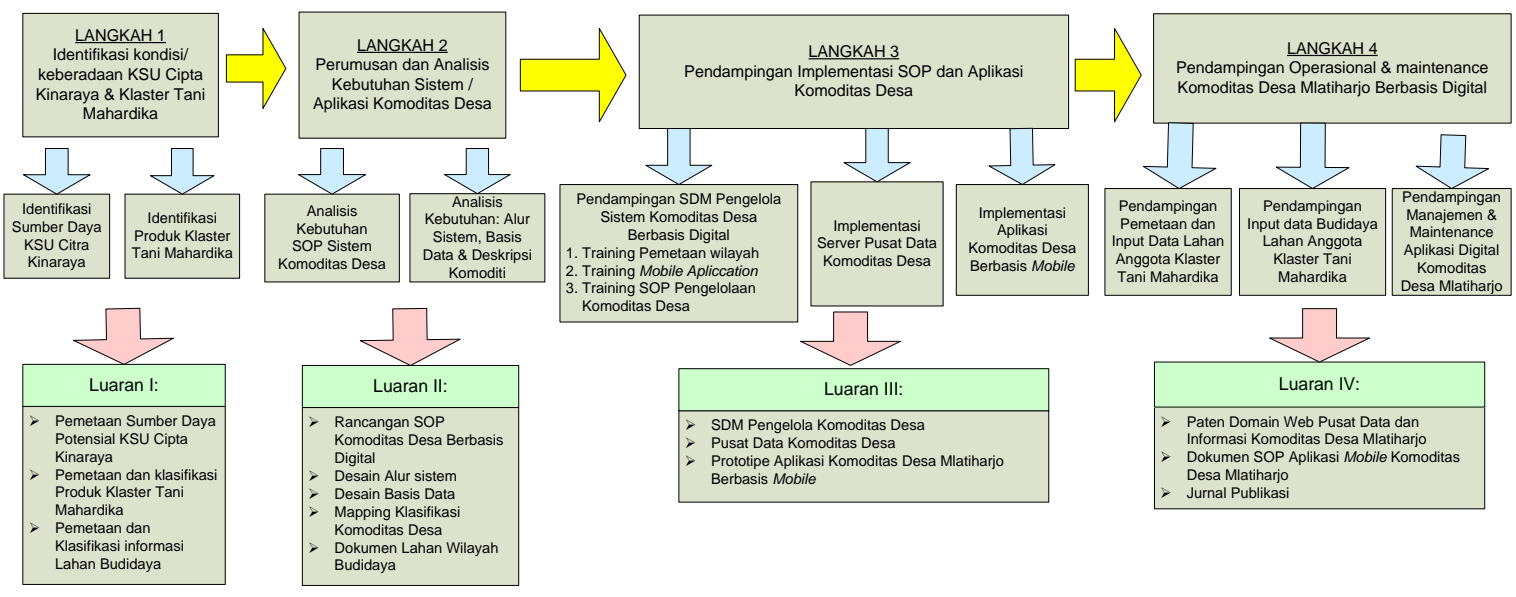

Gambar 2. Metode Penyelesaian Program $I_{b} M$ Desa Mlatiharjo

Pada langkah 1, dilakukan identifikasi kondisi/keberadaan KSU Citra Kinaraya dan Klastemr Tani Mahardika. Tahap ini merupakan kegiatan survei dan observasi untuk mendapatkan informasi dan data-data yang tepat antara lain pertama, sumber daya manusia yang terdiri dari 1) potensi pada bidang teknologi informasi dan komunikasi; 2) manajerial dan kepemimpinan. Kedua, infrastruktur manajemen dan kelembagaan, terdiri dari 1) AD/ART Kelembagaan; 2) Badan hukum kelembagaan; 3) Struktur Organisasi \& Job Description; 3) Manajemen keuangan. Ketiga, sarana dan prasarana, terdiri dari inventarisasi kelembagaan dan kelompok klaster. Keempat, data lahan anggota klaster, terdiri dari 1) pendataan informasi kependudukan anggota; 2) Pendataan informasi kepemilikan lahan budidaya; 3) Pendataan dan pendeskripsian jenis budidaya. Pada tahap ini, mitra harus berperan aktif dalam memberikan informasi dan data-data yang tepat kepada pelaksana program IbM. Alat bantu identifikasi pada tahap ini dapat berupa kuesioner dan form-form isian pendataan.

Langkah 2, yaitu perumusan dan analisis kebutuhan sistem / aplikasi Komoditas Desa. Pada langkah ke-2 ini mengajak mitra untuk merancang Standard Operational Procedure (SOP) Sistem Komoditas Desa berdasarkan potensi dari hasil langkah ke-1, antara lain 1) Prosedur untuk menampilkan profil pemilik komiditi; 2) Prosedur untuk menampilkan komoditas desa. 3) Prosedur untuk mengelola data perkembangan harga; 4) Prosedur untuk menampilkan estimasi total hasil produksi komoditas desa; 5) Prosedur untuk menampilkan waktu tanam komoditas desa; 6) Prosedur untuk menampilkan waktu panen komoditas desa; 7) Prosedur untuk menampilkan peta wilayah komoditas desa; 8) Prosedur layanan transaksi pemesanan komoditas; 9) Prosedur layanan transaksi penjualan komoditas; 10) Prosedur pembayaran pemesanan komoditas; 11) Prosedur pembagian hasil usaha ke anggota; 12) Prosedur sistem penjaminan validitas informasi komoditas. Berdasarkan kesepakatan rancangan SOP tersebut, maka dilakukan desain alur sistem dan basis data sebagai dasar membangun aplikasi Komoditas Desa Mlatiharjo.

Langkah 3 adalah pendampingan implementasi SOP dan aplikasi Komoditas Desa. Pada tahap ini akan melakukan uji SOP dengan cara simulasi. Pada rentang waktu yang sama juga 
dilakukan pelatihan kepada mitra antara lain pertama, pelatihan pemetaan wilayah. Pelatihan ini bertujuan agar mitra mampu memetakan lahan budidaya yang dimilikinya menggunakan alat-alat pemetaan digital sederhana yaitu menggunakan device mobile yang terjangkau untuk dimiliki mitra, sehingga letak geografis lahan mitra dapat ditampilkan oleh aplikasi map, antara lain google maps yang dapat ditampilkan di aplikasi web dan mobile Komoditas Desa, sehingga dapat membantu dalam pengelolaan wilayah budidaya komoditas di wilayah Desa Mlatiharjo. Selain hal tersebut, informasi pemetaan lahan juga membantu publik dalam mendapatkan informasi letak geografis komoditas yang dibutuhkan secara mudah dan jelas. Materi pelatihan adalah Global Positioning System (GPS). Dalam pelatihan ini, peran serta mitra adalah menyiapkan device mobile yang memiliki fasilitas GPS dan GPRS, dan informasi kepemilikan lahan yang benar. Data-data posisi geografis tersebut akan dipergunakan untuk menampilkan polygon wilayah lahan budidaya, dan data kepemilikan lahan sebagai informasi aset dan komoditas masyarakat desa di aplikasi Komoditas Desa.

Kedua, pelatihan mobile application. Komoditas Desa berbasis digital merupakan aplikasi berbasis mobile, dimana pada perancangan ini aplikasi dan basis data berada pada lokasi yang berbeda, basis data sebagai pusat data berada pada web server, dan aplikasi Komoditas Desa berbasis mobile berada pada sisi pengguna atau client. Oleh karena itu, dibutuhkan pelatihan guna mendapatkan ketrampilan dan pengetahuan tentang pengelolaan domain dan hosting web server bagi mitra sehingga dapat mengelola pusat data. Mitra juga dilatih untuk instalasi dan perawatan aplikasi berbasis mobile. Peserta pelatihan ini sebaiknya lebih dari 1 (satu) orang dari mitra, yang nantinya akan bertugas sebagai admin Komoditas Desa Mlatiharjo.

Pada waktu yang bersamaan, proses implementasi aplikasi Komoditas Desa berdasarkan alur sistem dan basis data langkah 2 juga dilaksanakan. Pada langkah 3, aplikasi Komoditas Desa selalu diuji coba dan dievaluasi berdasarkan perkembangan SOP pada saat simulasi langkah 3 yang dilakukan oleh mitra. Dengan demikian, tahap ini dapat menghasilkan SOP dan prototipe akhir aplikasi mobile Komoditas Desa Mlatiharjo yang merupakan penyempurnaan rancangan SOP, alur sistem dan kebutuhan basis data dari langkah 2 .

Langkah 4, yaitu pendampingan operasional \& maintenance aplikasi Komoditas Desa Mlatiharjo. Pada tahap ini domain dan hosting web server pusat data dan aplikasi Komoditas Desa Mlatiharjo harus sudah tersedia. Kemudian mitra memulai proses pengisian konten dan menjalankan aplikasi Komoditas Desa dengan didampingi oleh pelaksana program IbM untuk beberapa waktu guna menjaga terjadinya maintenance / perubahan struktur, dan terjadinya kesalahan pada aplikasi Komoditas Desa. Pada tahap ini juga, mitra sebagai pengelola mendapatkan pendampingan dalam hal manajemen dan maintenance aplikasi Komoditas Desa dalam bentuk aplikasi berbasis web. Konten sistem Komoditas Desa berupa informasi jenis-jenis komoditas, informasi waktu tanam, waktu panen, estimasi hasil, dan wilayah lahan serta profil pelaku usaha, dapat diakses publik melalui aplikasi web Komoditas Desa.

Pengembangan aplikasi sistem komoditas desa menggunakan model prototyping seperti terlihat pada gambar 3.

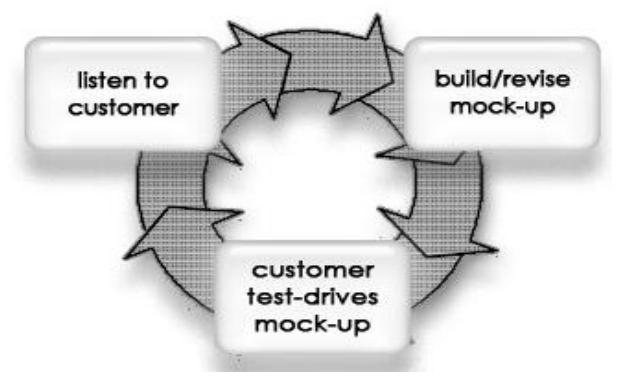

Gambar 3. Prototype Model[11]

Pada tahapan pertama, yaitu listen to customer atau information gathering tentang kebutuhan aplikasi yang akan dibangun. Pada tahap ini dilakukan wawancara dengan pihak mitra melalui kegiatan sarasehan atau Focus Group Discussion. Pada tahap ini menghasilkan ketentuan tentang actor sistem, yaitu Administrator, Layanan Pelanggan, Administrasi dan Keuangan, dan Pengiriman 
Barang. Tugas aktor Administrator adalah pertama, pengelolaan sistem / aplikasi dan keamanannya. Kedua, menjamin informasi ketersediaan produk dan pengelolaan konten. Aktor Layanan Pelanggan bertugas melakukan hubungan dengan customer dan public. Aktor Adminsitrasi dan keuangan bertugas mengelola proses transasksi dan laporan keuangan. Aktor Pengiriman Barang bertugas menjamin pengaturan barang yang akan dikirim ke Pembeli maupun Distributor.

Tahapan selanjutnya dalam metode prototype yaitu build/revise mock-up atau membangun aplikasi secara cepat. Pada tahap ini dilakukan pembuatan aplikasi Komoditas Desa berbasis web secara cepat. Proses pengembangan sistem ini lebih memfokuskan pada input output aplikasi sesuai dengan kebutuhan umum yang diketahui pada tahap pertama.

Tahap Customer Test-Drives Mock-Up. Pada tahap ini dilakukan uji dan evaluasi prototype oleh user yaitu pengguna seperti tahap wawancara. Uji dan evaluasi prototype digunakan untuk mendapatkan umpan balik apakah aplikasi sudah sesuai dengan kebutuhan user, yaitu actor sistem. Pengujian menggunakan cara uji fungsionalitas sistem, yaitu menggunakan metode Blackbox. Evaluasi dilakukan dengan cara wawancara dengan mitra. Jika evaluasi prototype belum sesuai dengan kebutuhan user, maka dilakukan proses perbaikan dimulai kembali ke tahap awal dan dilanjutkan ke tahap berikutnya. Untuk mendapatkan tanggapan yang lebih luas, maka dilakukan survei ke stakeholders usaha produksi komoditi pertanian dengan pengisian kuesioner sebagai uji responden.

Untuk dapat mewujudkan aplikasi komoditi desa yang dipergunakan sebagai pengelolaan komoditas pertanian desa Mlatiharjo, maka perlu dilakukan perancangan proses bisnis. Terdapat 10 (sepuluh) desain proses, antara lain 1) Proses Registrasi Petani; 2) Proses Validasi Registrasi Petani; 3) Proses Registrasi Pelaku Usaha; 4) Proses Input Peta Lahan; 5) Proses Unggah Komoditas; 6) Proses Validasi Unggah Komoditas; 7) Proses Validasi Unggah Komoditas Pasar Online; 8) Proses Belanja dan Pembayaran Online; 9) Proses Pengiriman Barang; 10) Proses Layanan Aduan.

Gambar 3 merupakan diagram alir proses regristerasi Petani. Jadi, Petani untuk dapat memiliki fasilitas pengelolaan informasi komoditas, Petani harus menjadi member sebagai aktor Petani. Terlihat juga pada gambar 4 bahwa Petani harus menerima term of service sistem untuk menjadi member, supaya menjaga agar semua member sistem dapat mentaati perarturan dan syarat bisnis yang berlaku sistem komoditas desa.

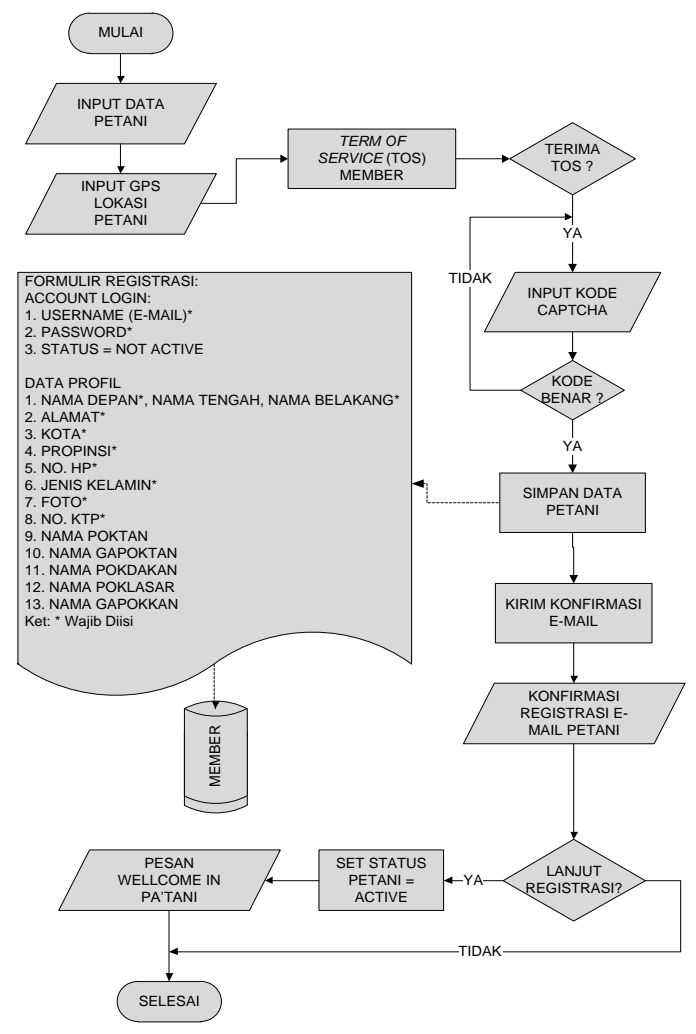

Gambar 4. Diagram Alir Regristerasi Petani 
Data registrasi Petani juga harus dapat diterima oleh aktor Adminsitrator. Proses ini dibuat untuk menjaga validitas konten berupa informasi pengelolaan usaha produksi komoditas oleh Petani. Jika Petani tidak dikenal maka dapat ditolak masuk sistem. Diagram alir proses validasi registrasi Petani dapat dilihat pada gambar 5 .

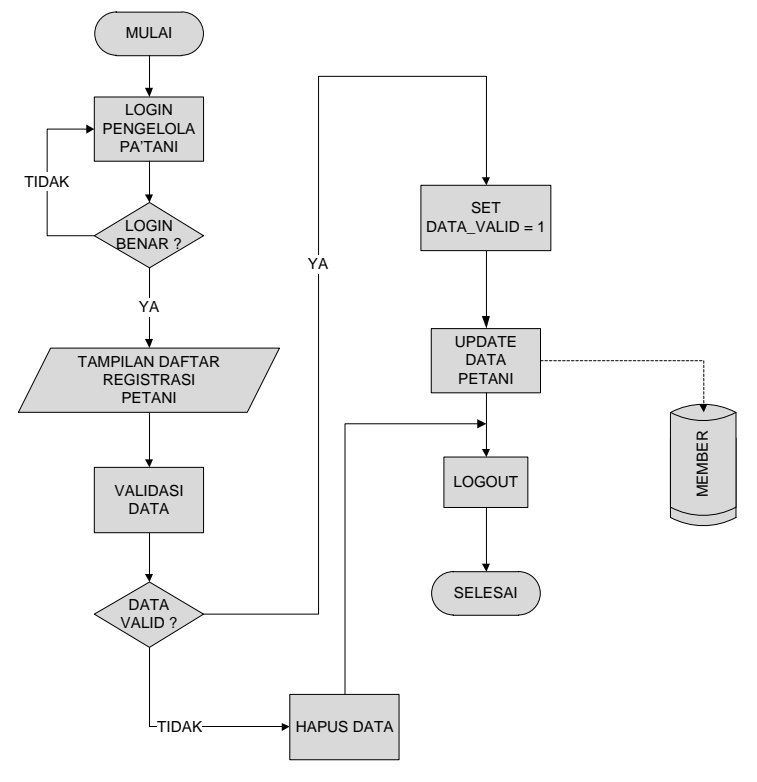

Gambar 5. Flowchart Proses Validasi Registrasi Petani

Seorang Petani jika berhasil menjadi member aktor Petani, maka dapat mengelola informasi usaha produksi komoditas sebagai komoditi pertanian milik Petani tersebut. Tahapan utama yang harus dilakukan oleh aktor Petani adalah memasukkan data lahan dan unggah komoditi. Proses memasukkan data lahan dapat dilihat pada gambar 5, sedangkan proses unggah komoditas dapat dilihat pada gambar 6 .

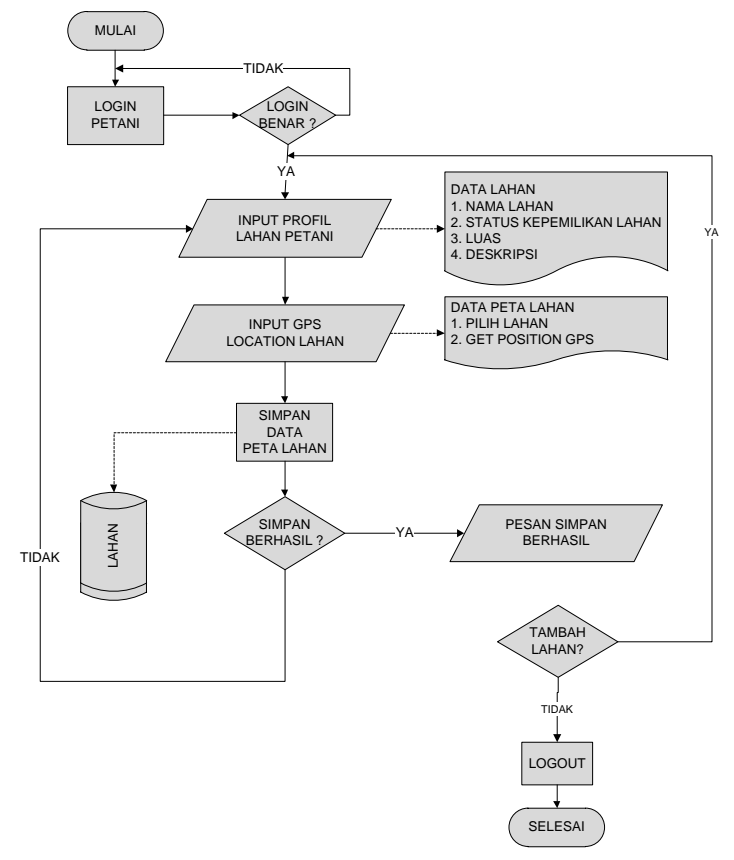

Gambar 5. Flowchart Proses Input Peta Lahan 


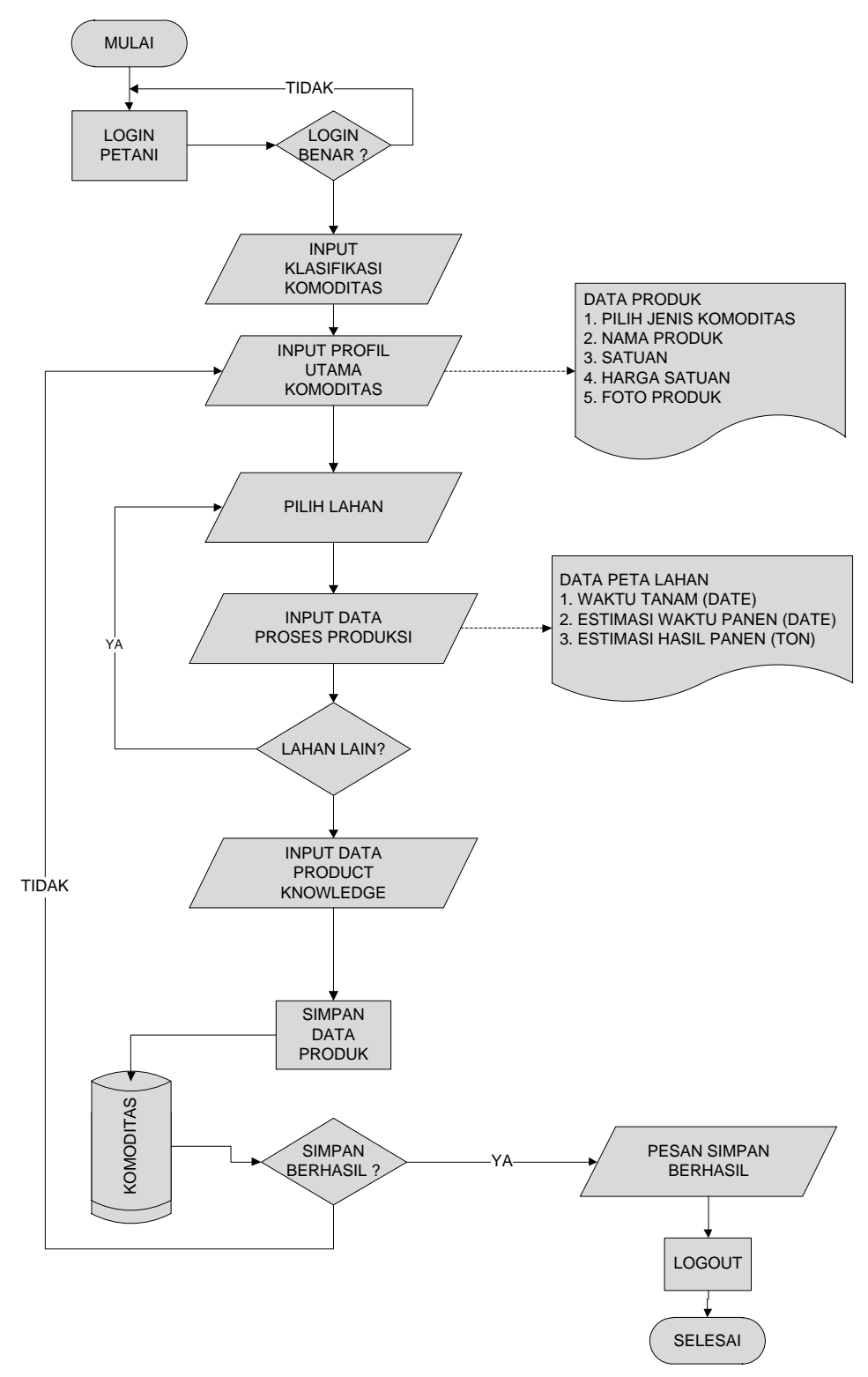

Gambar 6. Flowchart Proses Unggah Komoditas

\section{IMPLEMENTASI}

Pada bagian ini berisi tentang hasil dan pembahasan yang meliputi implementasi rancangan dan pembahasan aplikasi Komoditas Desa berbasis web. Pembahasan berisi uraian hasil implementasi berdasarkan hasil perancangan proses bisnis aplikasi. Sedangkan analisis hasil akan dilakukan terhadap hasil yang telah diuji dari aplikasi. Aplikasi Komoditas Desa berbasis web pada prinsipnya merupakan aplikasi pengelolaan komoditas pertanian. Aplikasi diimplementasikan menggunakan bahasa pemrograman PHP dan basis data MySql.

Aplikasi pengelolaan komoditas berbasis web, dirancang dan dibangun guna memberikan bentuk prototipe system informasi yang mampu mengelola komoditas pertanian hasil usaha Petani, serta sebagai pusat informasi dan komunikasi bagi para stakeholders usaha komoditas pertanian. Pada program $\mathrm{I}_{\mathrm{b}} \mathrm{M}$ Kemenristek Dikti 2016 ini mengambil kasus di Desa Mlatiharjo, Kecamatan Gajah, Kabupaten Demak, karena masyarakat petani yang tergabung dalam Klaster Pertanian Tani Mahardika dan koperasi KSU Citra Kinaraya, telah merasa perlu untuk memiliki sebuah sistem informasi guna pengelolaan usaha produksi bidang pertanian, khususnya pada tanaman pangan karena 
tuntutan para pelanggannya. Tampilan halaman Beranda aplikasi web sistem Komoditas Desa dapat dilihat pada gambar 7 .

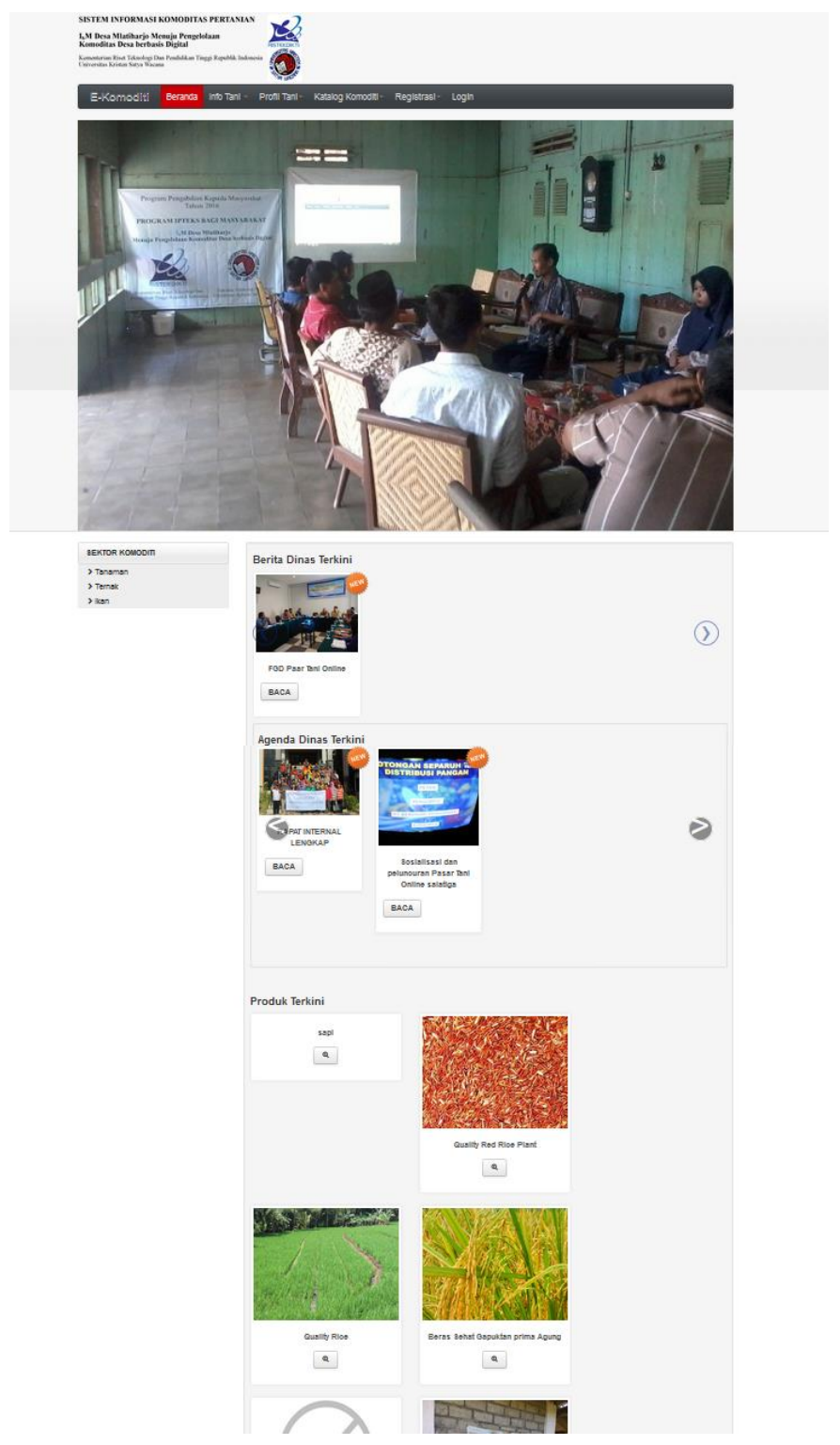

Gambar 7. Tampilan Aplikasi Komoditas Desa Berbasis Web

Pada halaman Beranda disediakan fasilitas untuk dapat menampilkan komoditas berdasarkan sektor pertanian, antara lain tanaman, peternakan dan perikanan. Informasi lain selain komoditas pertanian, juga dapat mengetahui profil dari stakeholders, antara lain Petani, Penyuluh, Pakar, Pelaku Usaha, Perbankan, Tenaga atau Buruh Tani, dan Deliver. Aplikasi Komoditas Desa ini juga dapat dipergunakan Petani sebagai katalog komoditas, yang memiliki data profil, informasi, dan pengetahuan (knowledge) produk komoditas. Product knowledge memiliki item informasi utama yaitu Info Produksi, yang berisi informasi antara lain waktu tanam, estimasi waktu panen, lahan yang digunakan, kapasitas produksi lahan, estimasi hasil panen, teknologi irigasi, dan progress report produksi. Dengan adanya Info Produksi tersebut, maka Petani dapat memberikan informasi lengkap tentang kegiatan produksi suatu komoditi kepada pelanggannya maupun publik. Tampilan detil produk komoditi dapat dilihat pada gambar 8. 


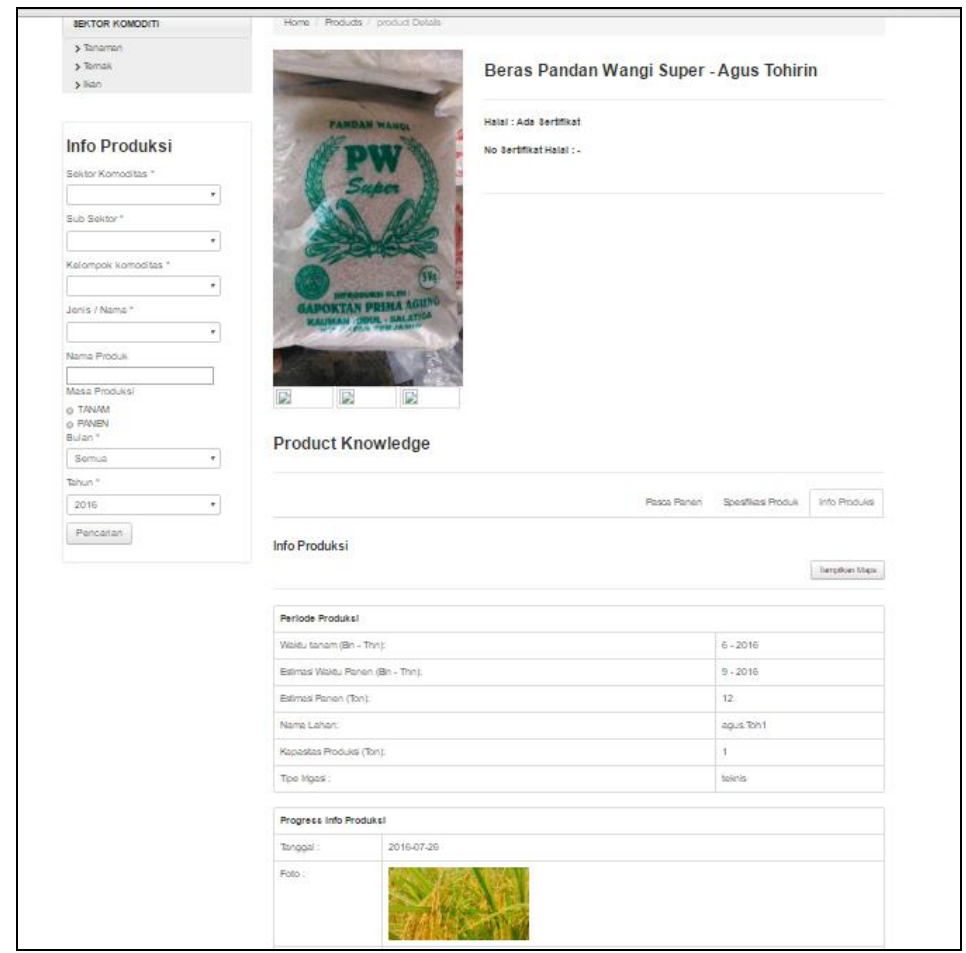

Gambar 8. Tampilan Detil Produk Komoditas Pertanian

Pada aplikasi Komoditas Desa juga disediakan layanan pencarian produk komoditi berdasarkan bulan dan tahun waktu tanam maupun waktu panen. Fasilitas ini disediakan guna para stakeholders dapat mencari informasi ketersediaan suatu komoditi pada suatu waktu yang diinginkan, dan menemukan Petani pemilik komoditas tersebut. Tampilan hasil proses pencarian berdasarkan waktu panen dapat dilihat pada gambar 9, dan gambar 10 tampilan halaman peta lokasi lahan tempat produksi komoditi.

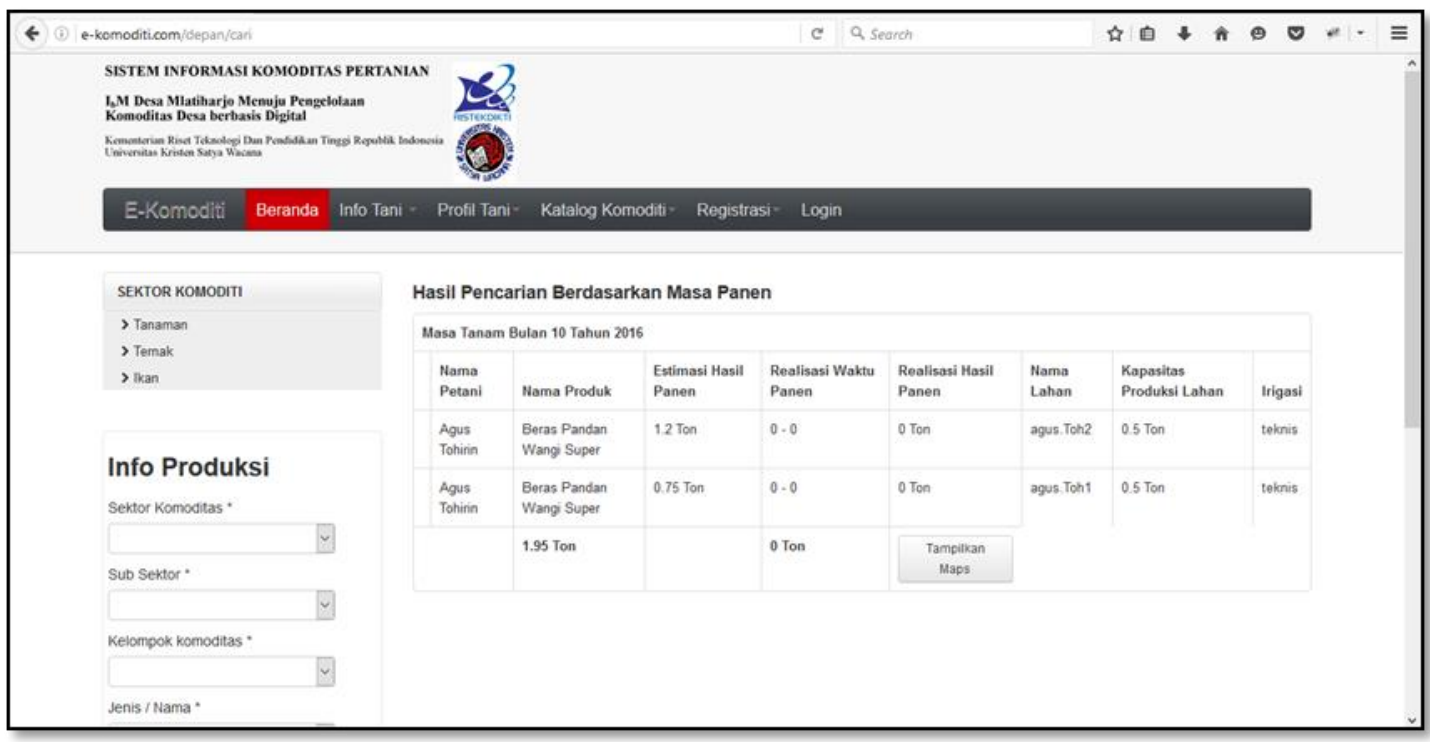

Gambar 9. Tampilan Hasil Pencaraian Komoditas Pertanian Berdasarkan Waktu Panen 


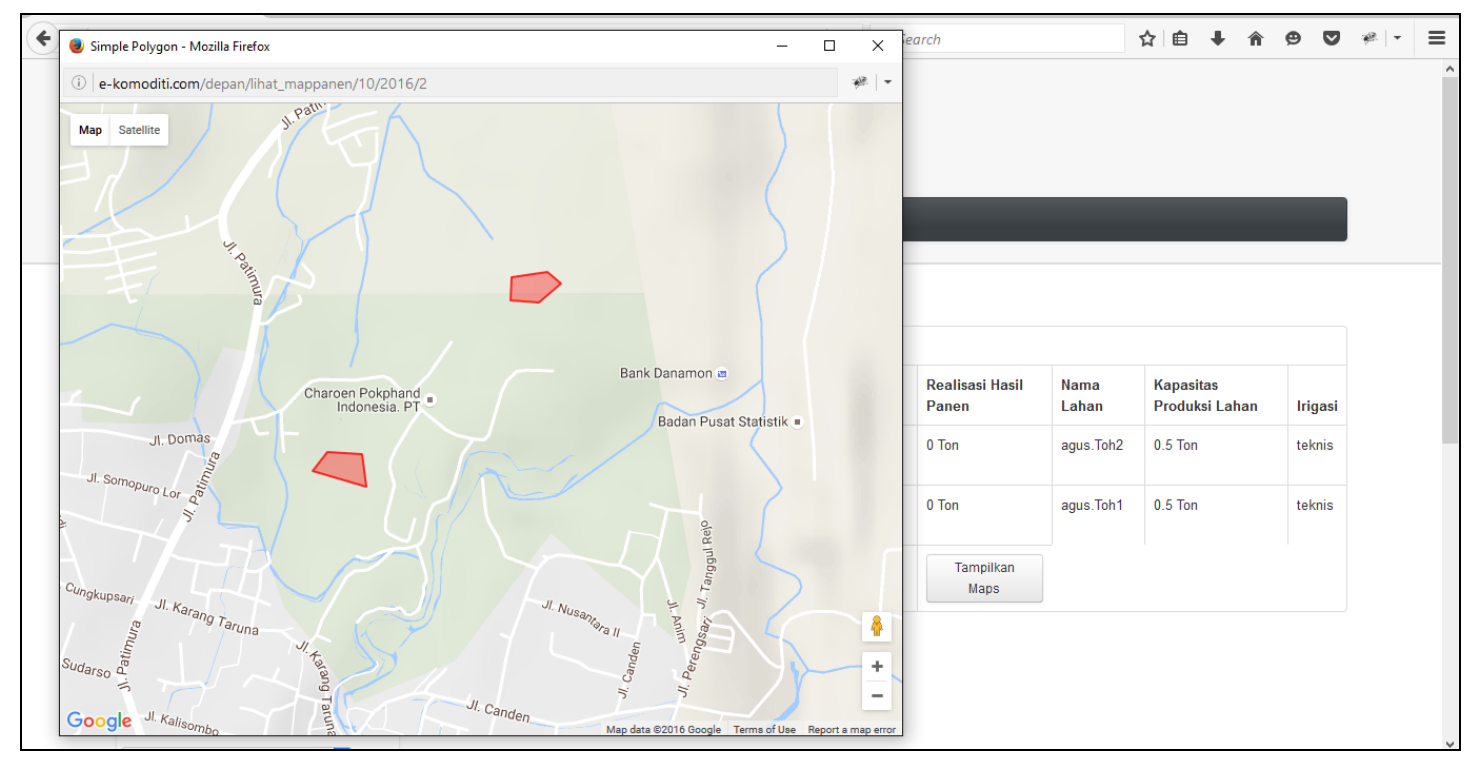

Gambar 10. Tampilan Peta Lokasi Produksi Suatu Komoditi Pertanian

Pada program IbM Desa Mlatiharjo Menuju Pengelolaan Komoditas Berbasis Digital ini dilakukan survei ke stakeholders agribisnis dan publik berjumlah 550 responden di beberapa kota di Jawa Tengah, antara lain Kelompok Tani Hidroponik Kota Kudus, PPL dan Petani anggota dan pengurus Klaster Pertanian Tani Mahardika Kabupaten Demak, dan stakeholder agribisnis Kota Salatiga dan sekitarnya. Survei dilakukan untuk mendapatkan tanggapan terkait pengembangan katalog produk baru yang diterapkan pada produk jenis barang berupa komoditi pertanian. Stakeholders yang dimaksud antara lain Dinas Pertanian, Peternakan dan Perikanan (Dispertankan), Pakar Pertanian, Petani, Pelaku Usaha, Perbankan, dan masyarakat umum. Tools yang dipergunakan adalah kuesioner, dan dianalisis menggunakan skala Linkert yang hasilnya lebih dari 75 persen dari stakeholders menyatakan setuju bahwa Sistem Informasi Komoditas Pertanian yang dibangun dapat dipergunakan sebagai pusat informasi usaha produksi komoditas pertanian suatu wilayah, dan dapat membantu Petani dalam melakukan pemasaran usaha produksi komoditasnya dimulai sejak saat mulai tanam, bahkan masih dalam bentuk rencana produksi yang akan dilakukan Petani tersebut.

\section{KESIMPULAN}

Kesimpulan yang dapat diambil dari hasil penerapan Ipteks khususnya teknologi informasi pada kelompok mitra di Desa Mlatiharjo pada program IbM Desa Mlatiharjo Menuju Pengelolaan Komoditas Desa Berbasis Digital adalah pertama, aplikasi Komoditas Desa yang dikembangkan sebagai hasil program pada hakekatnya merupakan aplikasi Komoditas Pertanian berbasis web dan mobile, yang mampu memberikan layanan kepada Petani untuk dapat mengelola informasi usaha produksi komoditi, sekaligus dapat berguna untuk pemasaran hasil usaha produksi komoditi. Kedua, aplikasi Komoditas Pertanian hasil program dapat dipergunakan oleh kelompok petani, kelompok usaha, dan lembaga pemerintah sebagai sistem pengelolaan dan pemasaran komoditas hasil pertanian, sehingga diharapkan dapat mempanjang waktu pemasaran, dan memperpendek rantai pasok komoditas pertanian antara petani dan konsumen.

Saran Pengembangan Sistem Komoditas Pertanian adalah dapat disosialisasikan dan diterapkan di desa atau kelompok petani yang lain di wilayah Indonesia, sehingga informasi usaha produksi komoditas pertanian dapat diakses oleh publik atau masyarakat, sehingga dapat mendukung program ketahanan pangan, pengendalian harga, dan kesejahteraan masyarakat khususnya Petani dapat terwujud. 


\section{DAFTAR PUSTAKA}

[1] Desa Mlatiharjo, 2014, Profile Desa Mlatiharjo Kecamatan gajah Kabupaten Demak Jawa Tengah, Pemerintahan Desa Mlatiharjo, Tidak Dipublikasikan.

[2] Sugiartono H., 2014, Data Penjualan Beras, Benih dan Bibit Klaster Tani Mahardika, Demak: Tani Mahadika, Tidak Dipublikasikan

[3] Utama C., 2011, Modul 1 Rekaya Web : Codeigniter Framework, Bandung: Teknik Informatika UNPAS.

[4] Rachmat C., A., 2012, Pengantar teknologi Mobile, http://www.dahlan.web.id/files/diktat/pTM/Pengantar\%20Teknologi\%20Mobile1. PPT. Diaksses pada tanggal : 4 November 2012

[5] Willbanks, Mike, 2011, Mobile:Push For Sync \& Notifications, Zend / PHP Conference, USA

[6] Susilo B., Nurjani E., Harini R. 2008. Aplikasi Sistem Informasi Geografis Untuk Analisis Kesesuaian Lahan Pertanian Di Propinsi Daerah Istimewa Yogyakarta. Majalah Geografi Indonesia. ISSN 0125-1790 MGI No. 2, Vol. 22, 165-177.

[7] Andriaty E., Setyorini E., 2012. Ketersediaan Sumber Informasi Teknologi Pertanian Di Beberapa Kabupaten Di Jawa. Jurnal Perpustakaan Pertanian. No. 1, Vol. 21, 30-35. http://www.ejurnal.litbang.pertanian.go.id/index.php/jpp/ article/viewFile/493/pdf.

[8] Pinuji R.A.S, 2014. Sistem Informasi Geografis Komoditas Dan Luas Lahan Pertanian Berbasis Android Di Kabupaten Magelang. http://digilib.uinsuka.ac.id/15753/1/BAB\%20I\%2C\%20VII\%2C\%20DAFTAR\%20PUSTAKA.pdf. Diakses tanggal 21 Februari 2018.

[9] Putra E. U., Yantu M. R., Sulaeman, 2015. Pengembangan Sistem Informasi Agribisnis Desa Labuan Toposo Kecamatan Labuan Kabupaten Donggala. e-J. Agrotekbis. ISSN : 2338-3011 No. 3 Vol. 3, 368-380.

http://jurnal.untad.ac.id/jurnal/index.php/Agrotekbis/article/viewFile/5098/3888.

[10] Kharis A., 2016. Sistem Informasi Geografis Pemetaan Lahan Pertanian Dan Komoditi Hasil Panen Kabupaten Kudus. http://eprints.umk.ac.id/5888/1/HALAMAN_UTAMA.pdf. Diakses tanggal 22 Februari 2018. 